\title{
EFFECT OF RELATIONSHIP MARKETING ON CUSTOMER RETENTION IN THE TELECOMMUNICATIONS INDUSTRY
}

\author{
Glory Sunday Etim ${ }^{1}$, Idorenyin Udo Etuk ${ }^{2}$, \\ Edim Eka James ${ }^{1}$ and Sarah Ekpe ${ }^{1}$ \\ ${ }^{1}$ University of Calabar, Department of Marketing \\ ${ }^{2}$ University of Calabar, Department of Business Management
}

Cite this article:

Glory S.E., Idorenyin U.E., Edim E.J., Sarah E. (2021), Effect of Relationship Marketing on Customer Retention in the

Telecommunications Industry. British Journal of Management and Marketing Studies 4(4), 68-81. DOI: 10.52589/BJMMSYIPPKDVZ.

\section{Manuscript History}

Received: 14 Nov 2021

Accepted: 1 Dec 2021

Published: 14 Dec 2021

Copyright $(9) 2020$ The Author(s). This is an Open Access article distributed under the terms of Creative Commons AttributionNonCommercial-NoDerivatives 4.0 International (CC BY-NC-ND $4.0)$, which permits anyone to share, use, reproduce and redistribute in any medium, provided the original author and source are credited.

\begin{abstract}
This study centered on the effect of relationship marketing on customer retention in the telecommunications industry. It was conducted to assess the effects of customer care, communication, trust-building and service quality on customer retention in the telecommunications context. The study adopted survey research design. A structured questionnaire was used to obtain primary data from 198 customers of MTN Nigeria Plc and Globacom Nigeria Plc in Calabar. The data were analyzed and interpreted using descriptive statistics, while the hypotheses developed for the study were tested using multiple linear regression. Consequently, the findings of the study revealed that customer care, communication, trust building and service quality had significant positive effects on customer retention of telecommunication firms in Calabar. Therefore, the study recommended that: telecommunications companies should strengthen their customer care capability by using trained service professionals to elicit and promptly resolve customers enquiries and complaints; telecommunications companies should improve communications with customers by opening up more channels such as phone calls, direct messaging, social media and email through which information can be transmitted to subscribers to enhance informed patronage decisions; and it is imperative for telecommunications companies to consolidate customers' trust in their delivery capabilities by demonstrating through effective service delivery that they are capable of satisfactorily meeting the service needs of subscribers.
\end{abstract}

KEYWORDS: Relationship Marketing, Customer Retention, Telecommunications 


\section{INTRODUCTION}

In today's world dominated by intense competition, high levels of consumer sophistication and environmental dynamism, it is increasingly difficult for business organizations operating under the transactional marketing philosophy to thrive. The reason for this, as suggested by Yulisetiarini (2016), is that for businesses to be able to enhance their competitive edge in a sustainable way, they have to consistently develop, nurture, promote and improve mutuallybeneficial and value-laden relationships with customers. This recognition among business organizations has resulted in the emergence and growth of the practice of relationship marketing, a marketing orientation that places a premium on quality customer relationships (Zhang, Watson, Palmatier \& Dant, 2016). According to Ibrahim, Jubril and Al-mustapha (2015), relationship marketing is about forming long-term relationships with customers that guarantees customer satisfaction and retention over the long run. Rather than trying to encourage a one-time sale, relationship marketing tries to foster customer loyalty by providing quality products and services capable of effectively meeting the needs and requirements of the target market (Karen \& Hayes, 2017).

Due to the enormous importance of relationship marketing, business organizations in various industries are rapidly converting their marketing approach to relationship marketing by committing to creating and sustaining strong bonds with customers through the delivery of high-quality services, customer care services, frequent communication and quick resolution of customers' complaints and service-related conflicts so as to enhance customers' trust and satisfaction (Luu, Ngo \& Cadeaux, 2018). The studies of Chakiso (2015); Bataineh, AlAbdallah, Salhab and Shoter (2015); Abtin and Pouramiri (2016) show that telecommunications companies around the world are designing and implementing various relationship marketing strategies such as building trust, communication, conflict handling, promise fulfillment, customer care and service quality with the aims of achieving customer satisfaction and retention. In the context of this present study, the focus was on customer care, communication, trust-building and service quality. Chakiso (2015) views customer care service as the provision of support or supplementary services to customers before, during and after making purchases to ensure they are satisfied. As a relationship marketing dimension, communication is the two-way flow of information between an organization and customers to create mutual understanding and resolve service-related issues or complaints (Luu, Ngo \& Cadeaux, 2018). Trust building is the establishment and promotion of trust in the minds of consumers in order to strengthen their confidence in the service provider's ability to satisfactorily deliver the promised service. Service quality is the result of the comparison between consumers' perceived service or expected service and actual service delivered by an organization. A qualitative service is one whose actual performance meets or exceeds customers' expectations (Bataineh et al.,2015).

In the face of an ever-competitive and dynamic industry, Nigerian telecommunications companies have sought to apply these relationship marketing strategies in an attempt to strengthen their marketing competitiveness. Nevertheless, telecommunication service subscribers in Nigeria often complain about the low quality of network services coupled with high service charges; and in some rural communities, network signals are not strong enough to provide dwellers with sufficient access to communication services. Similarly, Nosiri, Agubor and Ekwueme (2015) decried that when encountered with service-related issues such as network failure, tariff plan errors, browsing problems and even SIM replacement, subscribers experience great amount of delay before having these issues resolved by Nigerian 
telecommunications companies due to insufficient technology and/or personnel. These factors are why an average Nigerian maintains more than one network provider for communication purposes, without any firm loyalty to any of them, hence making it difficult for service providers to effectively achieve customer retention.

To address some of these challenges, Nigerian telecommunications companies have implemented relationship marketing strategies using several practices such as building trust, ensuring customer satisfaction, resolving customer conflicts, providing personalized customer care services and maintain seamless communication flows with consumers, as reflected in the scholarly studies of Ndubisi, Anyanwu and Cosmas (2016); Odili, Frederick and Nonye (2020); Adefarasin and Toludare (2018). Companies such as MTN, 9Mobile, and Airtel are applying certain relationship marketing practices such as providing customer care and conflict resolution services (which could be accessed by dialing 180 for MTN, 111 for Airtel and 200 for 9Mobile), ensuring customer satisfaction (by improving the quality of their voice and internet services), and encouraging communication flows with customers (through their social media platforms, mobile application software and customer support email addresses). This leads to the fundamental question which motivated the study: to what extent has the application of relationship marketing strategies by telecommunications companies improved their customer retention capacity? This study was therefore carried out to assess the effect of relationship marketing (customer care, communication, trust-building and service quality) on customer retention in the telecommunications industry.

\section{LITERATURE REVIEW}

\section{Relationship marketing}

Relationship marketing is an effort that intends to cultivate and nurture long-term, cost-efficient relationships between the company and its customers for the mutual benefit of both parties (Lovelock, 2005). Zeithaml and Bitner (2003) defined relationship marketing as a philosophy of doing business, a strategic orientation that focuses on keeping and improving current customers rather than on acquiring new customers. In the view of Chakiso (2015), relationship marketing is viewed as the activities carried out by business organizations for the purpose of attracting, interacting with and retaining more profitable or high net-worth customers. Relationship marketing basically entails establishing long-term relationships with customers. Instead of attempting to achieve a single one-time purchase by customers, relationship marketing promotes customer retention by offering high quality and valuable products and services (Shirley, 2017). Relationship marketing primarily involves the improvement of a company's internal operations, because customers may be lost not due to a dislike of the company's products or services; but because they were frustrated with the quality of its customer service. Rouse, Shaio and Aberle (2019) observe that relationship marketing is an aspect of customer relationship management (CRM) that focuses on promoting customer loyalty and long-term customer engagement instead of shorter-term goals like customer acquisition and individual sales. The purpose of relationship marketing is to create strong, even emotional, customer connections to a brand capable of guaranteeing ongoing business interactions, free word-of-mouth promotion and information from customers that can generate future leads for a company (Rouse, Shaio \& Aberle, 2019). In the telecommunications industry, relationship marketing entails attracting, developing and sustaining long-term customer 
relations that will enable telecom companies to gain a competitive edge over their competitors. The practice of relationship marketing is particularly important in the telecommunications industry because of the intangible nature of telecom services and the high level of customer trust required to maintain sustainable business relations (Chatterjee \& Kamesh, 2019).

\section{Customer retention}

Customer retention or loyalty indicates the extent to which customers are devoted to a company's products or services and how strong their tendency to select one brand over the competitors. Customer loyalty is positively related to customer satisfaction as happy customers consistently favor the brands that meet their needs (Alhassan \& Yousuf, 2012). Customers who are loyal are dedicated to patronizing a particular brand or company over others and do not display visible willingness to begin business relations with alternative brands. A firm's steady commitment to consistently produce high-quality products and deliver good service to customers is what fuels customer retention. As such, it is imperative for companies to be consistent in the quality of products or services offered to customers if they are to make customers loyal to their brands (Umar \& Jinaidi, 2012). Another practical way of enhancing customer retention is offering reward and loyalty programmes to repeat customers as a display of gratitude for their continued patronage amidst competing alternatives. In the view of Lewis and Maurice (2018), customer loyalty is the continued and regular patronage of a business in the face of alternative economic activities and competitive attempts to disrupt the relationship. Robert, Muller and Purcell (2018) assert that customer loyalty can be said to have occurred if people choose to use a particular shop or buy one particular product, rather than use other shops or buy products made by other companies. Customers exhibit customer loyalty when they consistently purchase a certain product or brand over an extended period of time.

\section{Customer care and customer retention}

Customer care is how customers are treated when they interact with a brand. It includes all experiences with the company and its employees before, during and after a purchase. Fontanella (2019) argued that customer care remains a critical part of customer service given that it encourages the development of harmonious emotional interrelationships between a brand and its target customers. It is the process of building an emotional connection with customers by offering support, advice and assistance to them at every point of service encounter. Eyonam and Kofi (2018) view customer care as the provision of support services to customers before, during and after their needs have been met. It is how a firm's personnel treat customers from the moment they walk into the shop until they leave. Politeness, respect, courtesy and empathy are the most attractive customer care attributes sought by customers. The quality of customer care service received by a subscriber determines their future purchase tendencies and loyalty. Taskus (2020) believes that customer care involves offering support services to customers to make certain that they enjoy satisfactory and exciting experiences with the company's products, services or brands. The delivery of fast-paced and supportive customer care services to customers has the capacity to boost customer satisfaction and encourage customer retention. This premise is supported by the study of Adefarasin and Toludare (2018), which revealed that customer care had a significant positive effect on customer loyalty of Mobile Telecommunications Network (MTN) in Lagos, Nigeria. The premise is also bolstered by the study of Husnain and Akhtar (2016), which revealed that customer care had a significant positive correlation and effect on customer loyalty towards Pakistani banks. 


\section{Communication and customer retention}

In the context of relationship marketing, communication is the back-and-forth transmission of information between a business organization and its customers in order to achieve established business objectives (Rajah \& Al-Islami, 2014). Communication is defined as the formal as well as informal exchanging and sharing of meaningful and timely information between buyers and sellers (Anabila, Narteh \& Tweneboah, 2012). Communication, in relationship marketing, involves keeping in touch with valued customers; providing timely and trustworthy information on service and service changes; and responding proactively if a delivery problem occurs (Ndubisi \& Madu, 2009). The seamless flow of communication between a service provider and service consumers provides the mechanism for the service provider to understand customers' needs and to satisfy them effectively, thereby improving customer retention. This assertion is corroborated by the study of Ibrahim, Jubril and Al-mustapha (2015), which revealed that communication had a significant positive impact on customer loyalty to privately-owned hospitals in Kaduna. The assertion above is also supported by the study of Ndubisi, Anyanwu and Cosmas (2016), which revealed that communication had a significant positive relationship and effect on consumer loyalty of Mobile Telecommunications Network (MTN) in Lagos.

\section{Trust-building and customer retention}

In the marketing context, trust is customers' confidence in the capacity of a firm to effectively and satisfactorily meet their needs and requirements. A customer trusts a firm when he believes and is assured that the firm has the expertise and competency to effectively serve his needs and wants (Bradley, 2018). In the view of Olayinka and Odunlami (2018), trust entails customers' expression of confidence or reliance in the ability of firms to provide products and services that are accurate, reliable, appropriate, valuable and capable of satisfying their needs and expectations. An organization can build trust with customers by being honest in all its operations; providing truthful and unadulterated information about the real performance or quality of its products and services; taking responsibility and apologizing to customers in the event of product or service defects; consistently delivering high quality products/services and ensuring to satisfactorily fulfill promises made to customers. Just as trust is a vital prerequisite for long term relationships among groups of people to survive, trust is also very consequential for the establishment and maintenance of relationships between a firm and its customers (Jackie, Robinson, Stuart \& Weller, 2017). Furthermore, Olayinka and Odunlami (2018) assert that the issue of building trust with customers is even more important and critical when it has to do with service marketing, due to the unique challenges of marketing services. Services are intangible, meaning the customer cannot see the quality of the service before paying for it, which makes customers more critical when it has to do with patronizing serviceproviders. Existing studies by previous researchers indicate that trust building significantly enhances customer satisfaction and retention. This position is backed by the study of Odili, Frederick and Nonye (2020), which found that trust building had a significant positive association with customer retention to telecom networks in Enugu. Similarly, the abovepresented position is reinforced by the study of Adefarasin and Toludare (2018), which revealed that trust building had a significant positive effect on customer loyalty of Mobile Telecommunications Network (MTN) in Lagos, Nigeria. 


\section{Service quality and customer retention}

Parasuraman, Zeithaml, and Berry (1988) defined service quality as "the global evaluation or attitude of overall excellence of services. Service quality is the difference between customer's perceptions and perceptions of service satisfaction or dissatisfaction formed by their experience of purchase and use of the service (Parasuraman, Zeithaml \& Berry, 1988). Offering consistently high-quality services is fundamental to growth, survival and competitiveness in the service industry because service in itself is intangible and can only be assessed after it is experienced. Hence, service consumers expect certain features and conditions which indicate the quality of services they would receive. That is where service quality has an indispensable role to play. It is incontrovertible that one of the major determinants of customer retention in the service industry is the quality of service delivery, which is why organizations in this industry are focusing more resources and attention to the quality of their services and how it can be improved sustainably (Umar \& Jinaidi, 2012). Service quality is indispensable in the marketing of services, because it has a direct effect on customer satisfaction, which in turn, influences customers' loyalty intentions and repeat patronage. This presumption is corroborated by the study of Husnain and Akhtar (2016), which found that service quality had a significant positive correlation and effect on customer loyalty towards Pakistani banks. Similarly, the assertion above is also supported by the study of Ndubisi, Anyanwu and Cosmas (2016), which revealed that service quality had a significant positive relationship and effect on consumer loyalty of Mobile Telecommunications Network (MTN) in Lagos.

\section{Empirical review}

Adefarasin and Toludare (2018) conducted a study on the "Impact of customer relationship marketing on customer loyalty of Mobile Telecommunications Network (MTN) in Lagos, Nigeria". The study adopted a quantitative research method to obtain primary data from 185 subscribers of Mobile Telecommunications Network (MTN) in Lagos with the aid of a structured questionnaire. Data analysis was done using descriptive statistics and multiple regression analysis in the Statistical Package for the Social Sciences (SPSS 22). The study found that customer care, commitment, communication, trust building and service quality had significant positive effects on customer loyalty of Mobile Telecommunications Network (MTN) in Lagos, Nigeria. Hence, the study reached the conclusion that customer relationship marketing had a significant positive impact on customer loyalty of telecommunications companies in Nigeria. Husnain and Akhtar (2016) examined "Relationship marketing and customer loyalty: Evidence from banking sector in Pakistan ". The study used a selfadministered structured questionnaire to obtain primary data from 200 customers of commercial banks in Islamabad, Pakistan. The data obtained were analyzed using inferential statistics (multiple regression and Pearson's Product Moment Correlation Coefficient). Consequently, the findings of the study revealed that promise fulfillment, customer care, communication, service quality and trust had significant positive correlations and effects on customer loyalty towards Pakistani banks. On the basis of these findings, the study concluded that relationship marketing significantly improves customer loyalty in the banking sector of Pakistan.

Similarly, Ibrahim, Jubril and Al-mustapha (2015) conducted a study on the "Impact of relationship marketing on customer loyalty to privately-owned hospitals in Kaduna". The study drew a sample of 168 customers of privately-owned hospitals in Kaduna from whom primary data were obtained using a research questionnaire. Data analysis was done for the study using 
simple regression in the Statistical Package for the Social Sciences (SPSS 21). The findings of the study revealed that all independent variables tested (communication, customer care, service quality and building trust) had significant positive impacts on customer loyalty to privatelyowned hospitals in Kaduna. Therefore, the study concluded that there is a significant positive impact of relationship marketing on customer loyalty to privately-owned hospitals in Nigeria. Furthermore, Ndubisi, Anyanwu and Cosmas (2016) conducted a quantitative study on the "Effect of relationship marketing strategies on consumer loyalty: a study of Mobile Telecommunications Network (MTN) Nigeria". The study used a semi-structured research questionnaire to obtain primary data from 158 subscribers of Mobile Telecommunications Network (MTN) in Lagos. Pearson's Product Moment Correlation Coefficient and multiple regression were used for testing the hypotheses of the study. The findings of the study revealed that communication, trust building, customer care, and service quality had significant positive relationships and effects on consumer loyalty of Mobile Telecommunications Network (MTN), while commitment had a negative insignificant relationship and effect on consumer loyalty in this regard. Hence, the study reached the conclusion that to a very large extent, relationship marketing significantly improves consumer loyalty in the Nigerian telecommunications sector. Finally, Odili, Frederick and Nonye (2020) conducted a study on "Relationship marketing and customer retention among telecom networks in Enugu". The study elicited primary data from a sample of 203 telecom subscribers in Enugu Metropolis using a structured questionnaire. The study hypotheses were tested using multiple correlation analysis. Consequently, the findings revealed that relationship marketing (service quality, trust building, customer care and promise fulfillment) had a significant positive association with customer retention to telecom networks in Enugu. Taking these findings into consideration, the study concluded that relationship marketing is significantly and positively related to customer retention in the telecom sector in Nigeria.

From a review of existing related studies, a conceptual model has been built for this study to visually depict the hypothesized association between relationship marketing dimensions and customer retention in the specific context of this study. From the conceptual model in Fig. 1, it can be seen that the predictor variable (relationship marketing) was disintegrated into specific measurement parameters (namely: customer care, communication, trust-building and service quality) and measured against the outcome variable, customer retention, which was also disintegrated into customer repeat patronage, customer satisfaction and positive word-ofmouth as indicators. Consequently, the model presumed that the dimensions of relationship marketing (customer care, communication, trust-building and service quality) were statistically related to customer retention in the telecommunications firms. 


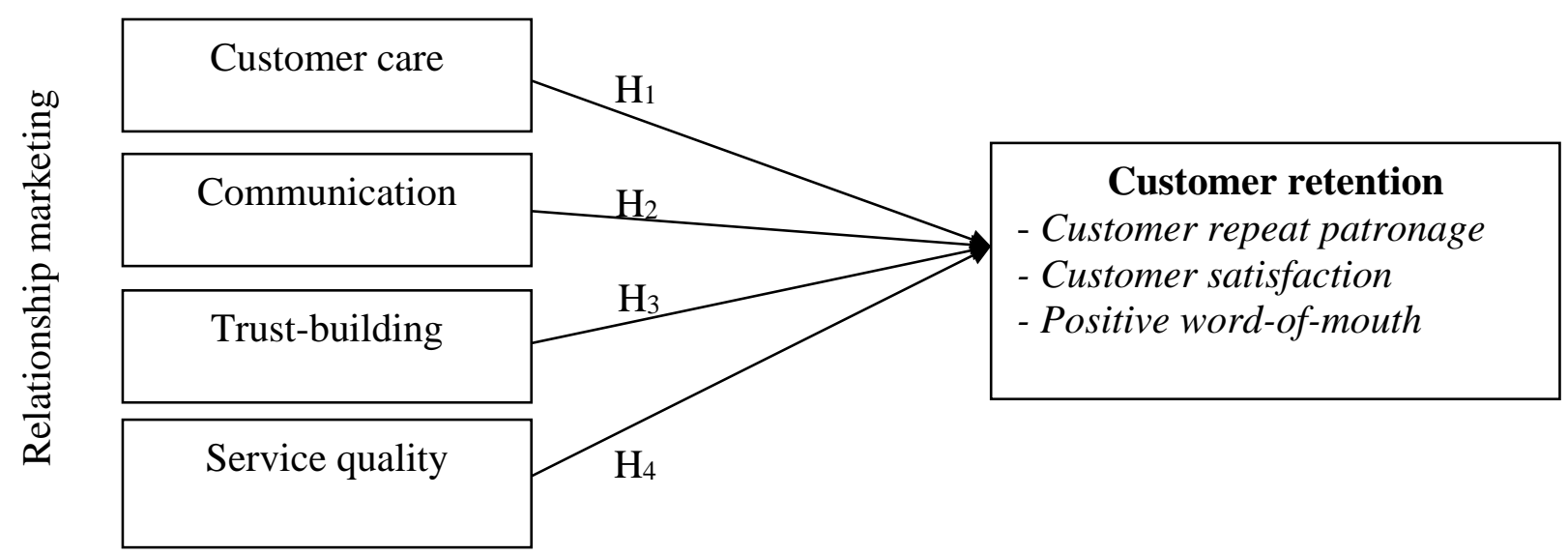

Fig. 1: Conceptual model of the study

\section{METHODOLOGY}

The study adopted cross-sectional survey research design, which enabled the collection of necessary primary data from target respondents at a single period of time for analysis and generation of findings. The study targeted a sample size of 207 customers of MTN Nigeria Plc and Globacom Nigeria Plc in Calabar, determined using the Topman sample size determination procedure. Potential respondents were sampled and included in the study by adopting convenience sampling technique. The instrument for data collection was a 15-item structured questionnaire confirmed for reliability through Cronbach's alpha reliability method. The Cronbach's alpha reliability coefficients for each of the study's variables are presented succinctly in Table 1. Having verified the instrument to be internally consistent, the researchers administered copies of the questionnaire to customers of telecommunications networks with the aid of a 2-member team of research assistants. The data obtained were analyzed and interpreted using descriptive statistics, whereas hypothesis testing was done using multiple linear regression in the Statistical Package for the Social Sciences (SPSS 23). The regression model specified for the study stated thus:

$Y=a+\beta_{1} X_{1}+\beta_{2} X_{2}+\beta_{3} X_{3}+\beta_{4} X_{4}+e$

Where:

$\mathrm{Y}=\quad$ Dependent variable (customer retention)

$\mathrm{a}=\quad$ The intercept

$\beta_{1}, \beta_{2}, \beta_{3}, \beta_{4}=$ Coefficients of the independent variable

$\mathrm{X}=\quad$ Independent variable (relationship marketing)

$\mathrm{e}=\quad$ Error margin $(5$ percent $)$ 


\section{Hence,}

$\mathrm{X}_{1}$ : Customer care

$\mathrm{X}_{2}$ : Communication

$\mathrm{X}_{3}$ : Trust building

$\mathrm{X}_{4}$ : $\quad$ Service quality

Table 1: Cronbach's alpha coefficients of the instrument

\begin{tabular}{lcc}
\hline \multicolumn{1}{c}{ Variables } & No. of items & $\begin{array}{c}\text { Cronbach's alpha } \\
\text { coefficients }\end{array}$ \\
\hline Customer care & 3 & .801 \\
Communication & 3 & .744 \\
Trust-building & 3 & .725 \\
Service quality & 3 & .793 \\
Customer retention & 3 & .799 \\
\hline
\end{tabular}

Source: Authors' computation via SPSS software (2021)

\section{RESULTS AND DISCUSSION}

\section{Hypothesis one}

Ho: Customer care has no significant effect on customer retention in the telecommunications industry.

\section{Hypothesis two}

Ho: Communication has no significant effect on customer retention in the telecommunications industry.

\section{Hypothesis three}

Ho: Trust building has no significant effect on customer retention in the telecommunications industry.

\section{Hypothesis four}

Ho: Service quality has no significant effect on customer retention in the telecommunications industry.

Independent variables: Customer care, Communication, Trust-building, Service quality

Dependent variable: Customer retention

Test statistic: Multiple linear regression

Decision criteria: Accept the alternative hypothesis if $(\mathrm{P}<.05)$ and reject the null hypothesis, if otherwise. 
British Journal of Management and Marketing Studies

ISSN: 2689-5072

Volume 4, Issue 4, 2021 (pp. 68-81)

www.abjournals.org

Table 2: Model summary of the effect of relationship marketing on customer retention in the telecommunications industry

\begin{tabular}{llrrr}
\hline Model & R & R Square & Adjusted R Square & Std. Error of the Estimate \\
\hline 1 & $.664^{\mathrm{a}}$ & .441 & .430 & .54848
\end{tabular}

a. Predictors: (Constant), Customer care, Communication, Trust-building, Service quality

Source: Authors' computation via SPSS software (2021)

Table 3: ANOVA ${ }^{\mathrm{a}}$ of the effect of relationship marketing on customer retention in the telecommunications industry

\begin{tabular}{llrrrrr}
\hline \multicolumn{1}{l}{ Model } & Sum of Squares & Df & Mean Square & F & \multicolumn{1}{c}{ Sig. } \\
\hline 1 & Regression & 45.870 & 4 & 11.468 & 38.120 & $.000^{\mathrm{b}}$ \\
& Residual & 58.060 & 193 & .301 & & \\
& Total & 103.930 & 197 & & & \\
\hline
\end{tabular}

a. Dependent Variable: Customer retention

b. Predictors: (Constant), Customer care, Communication, Trust-building, Service quality

Source: Authors' computation via SPSS software (2021)

Table 4: Coefficients of the effect of relationship marketing on customer retention in the telecommunications industry

\begin{tabular}{|c|c|c|c|c|c|c|}
\hline \multirow{2}{*}{\multicolumn{2}{|c|}{ Model }} & \multicolumn{2}{|c|}{$\begin{array}{l}\text { Unstandardized } \\
\text { Coefficients }\end{array}$} & \multirow{2}{*}{$\begin{array}{l}\text { Standardized } \\
\text { Coefficients } \\
\text { Beta }\end{array}$} & \multirow[b]{2}{*}{$\mathrm{t}$} & \multirow[b]{2}{*}{ Sig. } \\
\hline & & B & Std. Error & & & \\
\hline \multirow[t]{5}{*}{1} & (Constant) & 6.522 & .414 & & 15.748 & .000 \\
\hline & Customer care & .427 & .156 & .491 & 7.581 & .000 \\
\hline & Communication & .160 & .275 & .348 & 4.795 & .007 \\
\hline & Trust-building & .315 & .184 & .409 & 3.729 & .000 \\
\hline & Service quality & .272 & .167 & .325 & 4.057 & .000 \\
\hline
\end{tabular}

a. Dependent Variable: Customer retention

Source: Authors' computation via SPSS software (2021) 


\section{DISCUSSION OF RESULTS}

Tables 2, 3 and 4 present the multiple regression results of relationship marketing and customer retention in the telecommunications industry. According to the correlation coefficient $(\mathrm{R})$ in Table 2, it can be seen that the association between relationship marketing and customer retention in the telecommunications industry is 66.4 percent, which is very high. The coefficient of determination (R2) in the same table reveals that relationship marketing explains the variability in customer retention of telecommunications companies by up to 44.1 percent, when other factors remain unchanged. The association and effect of relationship marketing on customer retention in the telecommunications industry was considered statistically significant since the significance level (sig. 0.000) in Table 3 was less than the error margin of 0.05 . Furthermore, the following research findings could be summarized from Table 4: customer care, communication, trust-building and service quality had significant positive effects on customer retention in the telecommunications industry. This is because the p-values of the predictor variables $[$ customer care $(\operatorname{sig} .=0.000, t=7.581)$; communication $($ sig. $=0.007$, $\mathrm{t}=4.795)$; trust-building $($ sig. $=0.000, \mathrm{t}=3.729)$; and service quality $($ sig. $=0.000, \mathrm{t}=$ 4.057)] were less than the error margin of 0.05 .

Furthermore, these findings are substantiated by the scholarly studies of Adefarasin and Toludare (2018); Husnain and Akhtar (2016); Ibrahim, Jubril and Al-mustapha (2015); Ndubisi, Anyanwu and Cosmas (2016); Odili, Frederick and Nonye (2020), which also revealed that customer care, communication, trust-building and service quality had significant effects and associations with customer retention. The implication of these findings is that relationship marketing dimensions such as customer care, communication, trust-building and service quality possess the capacity to substantially improve customer retention; therefore, telecommunications companies could effectively enhance customer retention to their brands by applying these relationship marketing dimensions in their interactions with customers.

\section{CONCLUSION AND PRACTICAL IMPLICATIONS}

Over the past several years, researchers have sought to determine how business organizations could effectively improve customer retention in order to enhance their competitive position in the marketplace. One strategic option considered has been relationship marketing. Accordingly, scholars across the globe have conducted various studies to determine the effect and relationship between relationship marketing and customer retention in a number of industries including telecommunications. The findings of these studies generally support the premise that relationship marketing significantly enhances customer retention. To further verify the position of previous researchers, this study examined the effect of relationship marketing on customer retention in the telecommunications industry. The study obtained data from subscribers of telecommunications networks in Calabar and analyzed the data using descriptive and inferential statistics. Consequently, the study revealed that customer care, communication, trust-building and service quality had significant positive effects on customer retention in the telecommunications industry. These findings imply that telecommunications companies could significantly and positively improve customer retention to their services 
by effectively applying relationship marketing practices such as customer care, communication, trust-building and service quality. Consequently, the study concludes that relationship marketing has a significant positive effect on customer retention in the Nigerian telecommunications industry. From the findings of the study, some practical implications could be drawn to provide insights and guide managers in the telecommunications industry. Firstly, telecommunications companies should strengthen their customer care capability by using trained service professionals to elicit and promptly resolve customers enquiries and complaints. Secondly, telecommunications companies should improve communications with customers by opening up more channels such as phone calls, direct messaging, social media and email through which information can be transmitted to subscribers to enhance informed patronage decisions. Thirdly, it is imperative for telecommunications companies to consolidate customers' trust in their delivery capabilities by demonstrating through effective service delivery that they are capable of satisfactorily meeting the service needs of subscribers. Finally, to enhance customer retention to their services, telecommunications companies must consistently provide high-quality services to customers that are reliable, dependable and delivered by highly proficient service personnel.

\section{Limitations and Future Research}

Due to time and financial constraints, the scope of this study narrowly accommodated four relationship marketing dimensions, namely: customer care, communication, trust-building and service quality. Therefore, the study is incapable of explaining the effects of other relationship marketing dimensions (such as promise fulfillment, commitment, interdependence, reciprocity, value and empathy) on customer retention. Similarly, the study was a survey of customers to determine the effect of relationship marketing on their retention to telecommunications companies; therefore, the study is incapable of explaining the role of relationship marketing in improving the marketing performance of service providers. In light of the apparent limitations of this study, it is suggested that future studies incorporate more dimensions of relationship marketing to assess their influence on customer retention and/or overall marketing performance of service providers in the telecommunications industry or any other service-based industry. Studies of such nature would undoubtedly bridge the gaps left by this research, improve the generalizability of its findings and contribute to existing scholarly discussions on the subject.

\section{REFERENCES}

Abtin, A., \& Pouramiri, M. (2016). The impact of relationship marketing on customer loyalty enhancement (Case study: Kerman Iran insurance company). Marketing and Branding Research, 3, 41-49.

Adefarasin, W. \& Toludare, T. (2018). Impact of customer relationship marketing on customer loyalty of mobile telecommunications network (MTN) in Lagos, Nigeria. Annual Business Review, 7(2), 185-190.

Alhassan, J. \& Yousuf, R. (2012). Effect of customer relationship management on customer loyalty in the hotel industry of Lebanon. European Journal of Marketing, $37(12), 169-175$ 
Anabila, P., Narteh, B., \& Tweneboah, E. (2012). Relationship marketing practices and customer loyalty: Evidence from the banking industry in Ghana. European Journal of Business and Management, 4(13), 10 - 25

Bataineh, A. Q., Al-Abdallah, G. M., Salhab, H. A. \& Shoter, A. M. (2015). The effect of relationship marketing on customer retention in the Jordanian's pharmaceutical sector. International Journal of Business and Management, 10(3), 117-131

Bradley, G. (2018). The role of relationship marketing in the marketing performance of retail stores in Birmingham. Journal of Marketing Research, 6(3), 11-24

Chakiso, C. B. (2015). The effect of relationship marketing on customers' loyalty (Evidence from Zemen Bank). Emerging Markets Journal, 5(2), 58-70.

Chatterjee, D. \& Kamesh, A. (2019). Relationship marketing: Impact on bank customers' satisfaction. International Journal of Recent Technology and Engineering, 8(4), 8754-8760

Eyonam, J. \& Kofi, P. (2018). Analyzing the impact of customer relationship management on customer satisfaction and retention in the banking sector of Ghana. European Journal of Bank Marketing Management, 20(7), 18-26

Fontanella, C. (2019). What is customer care (as it relates to customer service)? Available at: https://blog.hubspot.com/service/customer-care (accessed 10 October, 2021)

Ibrahim, A., Jubril, R. \& Al-mustapha, N. (2015). Impact of relationship marketing on customer loyalty to privately-owned hospitals in Kaduna. Global Journal of Emerging Trends in Public Health Administration, 23(7), 14-30

Jackie, E., Robinson, W., Stuart, R. \& Weller, P. (2017). Impact of customer relationship marketing on customer patronage of privately-owned hospitals in Toronto, Canada. Journal of Public Health Administration, 3(2), 11-20

Karen, J. \& Hayes, I. (2017). Overview of customer relationship marketing. Available at: http://www.unlimitedbusinessideas.org/forum/karen-hayes-crm-overview.aspx (accessed 10 October, 2021)

Lewis, M. \& Maurice, O. (2018). Why customer loyalty matters. Available at: http://www.marketingsinsei.com/tutorials/why-customer-loyalty-matters.html (accessed 10 October, 2021)

Loverlock, K. (2005). Marketing management services (translation) index. Shakhan Publishers.

Luu, N., Ngo, L. V., \& Cadeaux, J. (2018). Value synergy and value asymmetry in relationship marketing programs. Industrial Marketing Management, 68, 165-176

Ndubisi, E. C., Anyanwu, A. V., \& Cosmas, N. (2016). Effect of relationship marketing strategies on consumer loyalty: a study of Mobile Telecommunications Network (MTN) Nigeria. International Journal of Management and Commerce Innovations, 3(2), 798-810

Ndubisi, N. O. \& Madu, C. N. (2009). The association of gender to firm-customer relationship. International Journal of Quality and Reliability Management, 26(3), 283-301

Nosiri, O. C., Agubor, C. K., \& Ekwueme, E. U. (2015). Telecom infrastructure sharing, a panacea for sustainability, cost and network performance optimization in Nigeria telecom industry. International Journal of Scientific \& Engineering Research, 6(8), 621-626. 
Odili, G., Frederick, I. \& Nonye, P. (2020). Relationship marketing and customer retention among telecom networks in Enugu. Journal of Marketing Management and Consumer Behavior, 2(2), 120-129

Olayinka, H. \& Odunlami, P. (2018). Customer relationship marketing and customer patronage among commercial banks in Oyo State, Nigeria. European Journal of Advanced Consumer Behaviour Research, 27(8), 178-189

Parasuraman, A., Berry, L., \& Zeithaml. (1985). A conceptual model of service quality and its implication for future research. Journal of Marketing, 46(4), 41-50.

Rajah, N. \& Al-Islami, K. (2014). Impact of relationship marketing on customer satisfaction and retention in the fast-food industry in Mali. European Journal of Marketing, 37(2), 169-176

Robert, N., Muller, S. \& Purcell, D. (2018). Relationship marketing and customer loyalty: Application of the commitment-trust theory. Journal of Emerging Trends in Personnel Management, 23(12), 10-21

Rouse, M., Shaio, D. \& Aberle, L. (2019). Relationship marketing. Available at: https://searchcustomerexperience.techtarget.com/definition/relationship-marketing (accessed 10 October, 2021)

Shirley, C. (2017). Relationship marketing: Explore the strategy of relationship marketing. Available at: https://www.marketing-schools.org/types-ofmarketing/relationship-marketing.html (accessed 10 October, 2021)

Taskus (2020). Customer care: Definition. Available at: https://www.taskus.com/glossary/customer-care/ (accessed 10 October, 2021)

Umar, N. \& Jinaidi, H. (2012). Service quality: Potential and problems. Global Journal of Innovation \& Technology, 22(5), 12-27

Yulisetiarini, D. (2016). The effect of relationship marketing towards customer satisfaction and customer loyalty on franchised retailers in East Java. Mediterranean Journal of Social Sciences, 7(1), 333-346.

Zeithaml, V. A. \& Bitner, M. J. (2003). Service marketing: Integrating customer focus across the firm (3rd Ed.). Tata McGraw-Hill.

Zhang, J. Z., Watson, G. F., Palmatier, R. W., \& Dant, R. P. (2016). Dynamic relationship marketing. Journal of Marketing, 80(5), 53-75. 